\title{
Incompatibility of Laws and Natural Resources: A Case Study of Land Revenue Laws and Their Implications in Federal Areas of Pakistan
}

\author{
Syed Arshad Hussain Shah, Syed AKHTER HuSSAIN SHAH, and MAHMOOD KHALID
}

\section{INTRODUCTION}

Better rule of law would generate economic growth, which would in turn build constituencies for democratic reforms [Root and May (2006)]. Consider prisoners dilemma, to Law and Economics Scholars, the inevitability of prisoner's dilemmas arising to block potentially efficient exchanges explains the need for and consequently the adoption of contract law. When the law enforces contracts, it permits the participants in a potential prisoners' dilemma the option of escaping the dominant strategy equilibrium of non-cooperation, which prevents the achievement of efficient exchanges, by permitting the parties to effectively pre-commit to future cooperative behavior. Mutual pre-commitments can produce the efficient cooperate-cooperate equilibrium. The existence of contract law then tends to foster efficient cooperative behaviour.

Institutions are considered to provide the mechanisms by which individuals can resolve social dilemmas [Steins (1999)]. They are sets of rules that people have created in order to control/regulate the behavior of people using a natural resource. Several layers of institutions are important for institutional development and economic performance. These layers, from the slowest moving to the fastest moving are: human motivations and social institutions, political institutions, legal institutions and private institutions [Azfar (2006)].

Institutions perform their role to frame rules, procedure and enabling environment for implementation of rules. Rights of individuals are recognised and recognised through institutions as well.

According to Wikipedia, Coase theorem, attributed to Ronald Coase, relates to the economic efficiency of a government's allocation of property rights. In essence, the theorem states that in the absence of transaction costs, all government allocations of property rights are equally efficient, because interested parties will bargain privately to correct any externality. The transaction costs and other inefficiencies might lead to reduction of natural bargains, thereby lead to inefficient allocation of resources, e.g. in

Syed Arshad Hussain Shah is Advocate of the High Court and Legal Adviser, Federal Board of Revenue, Islamabad, Syed Akhter Hussain Shah<akhterhshah@yahoo.com>is Additional Secretary, Finance, Government of the NWFP. Mahmood Khalid <mahmoodkhd@yahoo.com> is Research Economist, Pakistan Institute of Development Economics, Islamabad.

Authors' Note: We acknowledge valuable comments of Dr Eatzaz Ahmad, Dr Nisar Hussain Hamdani, and Dr Wasim Shahid Malik. Encouragement given by Dr Nadeem Ul Haque and Dr Rehana Siddiqui is recognised. However, views presented in the paper are personal to authors and have no concern with the organisations in which they serve. 
Pakistan every lease agreement beyond one year must be registered and stamped leads to lessor and lessee agreeing a lease agreement of 11 months or stay unregistered [Rafay (2006)]. This creates hidden economy as well as leaves rights unprotected in case of a conflict. Enforcement mechanism is weak, for instance a person executing unregistered legal instrument would be charged with only Rs 500 and the instrument would not be canceled thereto as well [Alam (2006)], which further suggests that it does not create a transaction cost to deter some bargains at all, while on the other hand mandatory registration requirements for any immovable property bargain is one such cost. Further the complexities, cumbersomeness and documentation requirements over and above those which are of a particular law binding create the transactional inefficiencies.

Contradicting legal practices based on type of presentation made also create a threat of rights violation to the bargainer as well as create the unidentified economic activity. The difference between definition of a Sale defined in Islamic Law differ slightly from the requirements of the Transfer of Property Act, 1882 but in certain cases its more, e.g. in the case of law relating to pre-emption [Alam (2006)].

\section{NATURAL RESOURCE MANAGEMENT AND THE ROLE OF THE LAWS}

Land being a fix supply natural resource and a fundamental factor for firm and household level production function requires a comprehensive short run and dynamic allocation mechanism. This would ensure its optimal utilisation, sustainability and adding value to the wellbeing of its users. In the broader perspective it encompasses factors such as optimality in usage, equity, sustainability and economies of scale. As this factor has multifaceted usage and in each of its dimensions requires a judicious use. E.g. from the property rights perspective it's an individual good, from the provision of a park or a recreational place makes it a public good etc. From the public ownership to the private, directed to the undirected, tenure based provision to the forever ownership makes it a complex object which requires a dynamic law for its optimal usage.

In the absence of the protection of property rights, many exchanges would not take place which are necessary and sufficient condition for welfare models and thereby markets would remain primitive and stunted. Reliable law enforcement is an important, indeed essential, public good that the state must provide to encourage economic development [Azfar (2006)]. Such a rule of law where rights and privileges of merchants and other citizens are clearly defined, impartially interpreted, and consistently enforced is important to facilitate economic activity.

Few of the Studies focusing on Interaction of law and economics is based on the human relationship. Although, Economists, who regard equilibria as self-sustaining, have easily concluded that equilibrium conditions in relationships will be self-enforcing and thus create "rights" among the relating parties which exist independently of any exogenous legal entitlements and the law does not attempt to intervene in ongoing relationships except to terminate them [Bowes and Bigelow (1996)]. In presence of rules of game such an equilibrium may easily be reached by players. But absence of rules of the game may affect overall efficiency of the system otherwise.

Role of judicial system is an important element in implementation of laws. It depends on how courts are used; it can be used to protect wealth rather than to protect competition and innovation or the governments may employ courts to improve contract 
enforcement, loan repayment and bureaucratic discipline and still not allow citizens the right to assemble, mobilize and organise for political purposes [Root and May (2006)].

Political institutions consist of the methods of selecting the government. A growing consensus in recent years suggests that this is because in many underdeveloped countries, privileged elite maintain their rents by forcing suboptimal policies on the rest of the population through oppressive political institutions [Rajan (2006)]. Initial inequality in endowments and opportunities can create constituencies that support bad policies which reproduce those initial constituencies over time.

New Institutional Economics (NIE) proposes clear property rights which give private agents sharp incentives to minimise on costs while maintaining quality. In the private economic sphere, collateral laws that clearly state creditors should be paid back in the order in which they lent may help improve the functioning of debt markets. Further there exists a need for ensuring a system of law enforcement commensurate with the requirements of self-sustained economic growth [Haq (2006)].

Business surveys based on investor perceptions typically correlate judicial reforms as a positive step towards advancing political stability and political opening [Root and May (2006)]. The New Institutional Economics (NIE) talks of governance and economic growth. While elaborating NIE Azfar (2006) used four subject; finance and development, education reform, decentralisation and the delivery of foreign assistance and concluded that each of them can be analysed in the NIE perspective. Political institutions and social structure affects laws like commercial laws and their enforcement hence affecting the debt and equity markets. Decentralisation and local institutions with reference public service delivery and accountability are also one of the core areas under the NIE.

\section{INCOMPATIBILITY OF FEDERAL LAND REVENUE LAWS}

The constitution of Pakistan seeks to promote well being of the people and protect economic life of Pakistan by conferring fundamental rights, including economic rights and then protecting them by declaring laws inconsistent with them to be void [Hassan (2006)]. Law endows certain rights to individuals engaged in economic transactions, but if these entitlements ${ }^{1}$ are not beyond those they can self-enforce, that such exogenous law would be ineffectual, or enforce "Unenforceability Hypothesis". The Objectives resolution, now part of the constitution of 1973, inter alia, established the guarantee of accession for fundamental rights, equality of status and opportunity before law, social, economic and political justice [Hassan (2006)].

Well established property rights are pre-requisite for establishment of a market economy. In the property rights theory the main focus is not so much on the different owner positions, but more on the conventional fourfold distinction of property right regimes. Cole (2002) documents following property rights:

State Property. Individuals have a duty to observe use/access rules determined by a controlling/managing agency. Agencies have a power to determine use/access rules.

Private Property. Individuals have a privilege (reinforced with claim rights) to undertake socially acceptable uses, and have a duty to refrain from socially unacceptable uses. Others (called 'non owners') have a duty not to prevent socially acceptable uses, and have a claim that only socially acceptable uses will occur.

${ }^{1}$ See Annexure 2 for details on bundle of rights. 
Common Property. The management group (the 'owners') has a power to exclude nonmembers, and nonmembers have a duty to abide by such exclusion. Individual members of the management group (the 'co-owners') have both powers and claims-duties with respect to the user rates and maintenance of the object owned.

Non-property. There is no defined group of users or 'owners' and the benefit stream are available to anyone. Individuals have both a privilege and a no claim with respect to use rates and maintenance of the asset. The asset is an 'open-access resource'.

Most economists would say that resources should be regulated by assigning one of these property right regimes.

Land revenue system in Pakistan has many ambiguities that land records do not reflect exact rights and interests of concerned parties to engage in bargains of immovable property, and lack of conceptual clarity. Overlapping laws creates an uncertainty and a setback to potential transactions of land.

A number of ambiguities in revenue laws are related to its property rights mentioned under following categories:

(1) Khana Milkiat.

(2) Khana Kasht.

(3) Abadi Deh.

(4) Shamlat and different kinds of shamlat.

(5) Private path and public path/shara-i-aam.

Strengthening of property rights and the expansion of competition and associated opportunities will help the very poor but with it endowments like education development is necessary [Rajan (2006)]. Describing the Taxonomy of land records, Khan (2006) identified that the system of land records are 5 centuries old, there is no single agency to coordinate titles or registration and state does not guarantee land titles. The formed rules are not being practiced and there is too much flexibility in the transfer of owner ship of land title (more than hundred). There is Qabza group and military interests in real estates.

Similarly overlapping property rights due to columns of holding as section 4 of Land Revenue Act 1967 states; "Word 'Holding' meaning of vernacular equivalent of term 'Holding' is Khewat and tenants' holding is called 'Khatooni' or 'Khata' . Word 'Khata' some times is loosely applied to owner's holding as well as tenant's holding. Tenant's holding is technically called 'tenancy' PLD 1984 SC (AJ\&K) 38 PSC 1984.

From the analysis of old and uncorrected ownership record of 1970s revealed that Khawat or Khata have lost their utility due to multiple distributions. Kind of property reflected through number Khasra is converted from rural/agriculture into semi-rural, urban and sub-urban. Mere entry in revenue record cannot be accepted as a sufficient proof of ownership rather the entry has to be interpreted in the light of other facts and circumstances of given case of CLC (1982), page 1309. Contract between proprietary body and non proprietary body of village are mentioned in CLC (1989), page 2148, Shariat-i-Wajibul Arz.

The old revenue laws are insufficient to cater for current needs of ownership of land in prevailing circumstances due to following reasons: 
(1) Size of land is same while population has increased many folds. In words demand has increased against constant supply (as land being a fixed supply resource).

(2) Old social system comprising close society and tribal system has evaded. The old social system was a check on violation of ownership rights.

(3) Social changes in the society have changed preferences of individuals. They prefer monetary interests over social values. Marginal utility of money is higher relative to marginal utility of social values.

(4) System governance is insufficient to strengthen property rights. A number of agents are involved in the system including revenue, police officials and politician. Due to heterogeneous and confusing roles and functions, it leads to weaken title of ownership.

(5) Escalating prices of land have increased value of marginal utility of land to individuals; therefore, they attempt to get utility of land even with insufficient land title. That also helped in growth of land mafia.

(6) Priority of land owners have been changing. They prefer developing and selling land instead of cultivating the same.

Land mafia, take benefit of such loose situation and exploit poor and weak land owners. They purchase share of the poor at very low rates, after attaining possessions, in most of the cases legalise their possession and sell it at higher price. This situation results in quarrels and chain of litigation.

The transaction costs and other inefficiencies might lead to reduction of natural bargains, thereby, lead to inefficient allocation of resources, e.g. in Pakistan every lease agreement beyond one year must be registered and stamped leads to lessor and lessee agreeing a lease agreement of 11 months or stay unregistered [Alam (2006)]. This creates hidden economy as well as leaves rights unprotected in case of a conflict. Enforcement mechanism is weak, for instance a person executing unregistered legal instrument would be charged with only Rs 500 and the instrument would not be canceled thereto as well [Alam (2006)], which further suggests that it does not create a transaction cost to deter some bargains at all, while on the other hand mandatory registration requirements for any immovable property bargain is one such cost. Further, the complexities, cumbersomeness and documentation requirements over and above those which are of a particular law, creates the transactional inefficiencies.

Contradicting legal practices also create a threat of rights violation to the bargainer as well as create the unidentified economic activity. The difference between the definition of a sale defined in Islamic Law differ slightly from the requirements of the Transfer of Property Act, 1882 but in certain cases its more, e.g. in the case of law relating to pre-emption [Alam (2006)].

In Pakistan, the Legal System ${ }^{2}$ is divided into customary, Islamic, and Official categories, each with its distinct legal traditions, and have developed their own clients and niches representing yet the distinct phases of the history of the region with no change in their proportions [ Chaudhry (2006)]. Vast majority of people live in rural areas which are predominantly ruled by customary/folk Islamic laws and not the official ones.

${ }^{2}$ See Annexure 1 for definitions of legal institutions. 


\section{IMPLICATIONS FOR LAND MANAGEMENT IN THE FEDERAL AREAS OF PAKISTAN}

Incompatibility of revenue laws, insufficient implementation mechanism and misinterpretation of laws have a number of implications. Many a time legally recognised relationships may not be substantially a part of economic relationships, and two categories of rights may not be co-extensive. Rules of game for determination of rights of individuals for marketable gains are required. Framing and implementation of rules draws its foundation on a governance system. For optimal governance, a legal regime must constitute a nested system of powers and authorities, so that it can adapt to changing circumstances, changes in institutional contexts and new scientific insights [Dietz, et al. (2003)].

\section{Weak Social System}

The existence of informal systems for deciding conflict (whether economic or else) and proportionate influences on formal as well as informal system has lead to limited success in social engineering aspect of formal law system in Pakistan [Azam (2006)]. Further the official system along with Islamic and customary laws are coherent with the local culture and are influenced by personal relations, ethnicity, money and influence customs.

\section{Crime}

Poverty, Income inequality, unemployment, low wages, weak law enforcement both from the quantity and quality aspect, weak institutions could be attributed to law breaching. Harrison and Gfroerer (1992) found that 26.1 percent of persons booked for any violent crime, and 24.7 percent of persons booked for any property crime used alcohol, cannabis and cocaine. Haq (2006) also analysed the impact of lawlessness on economic development using extended CGE model, and suggested that there is a two way causal relationship.

In the present study data analysis shows that in Islamabad in a year total numbers of litigations registered in district courts are around 12,000. Out of these litigations revenue related are more than 8000 in a year. In addition, district revenue officers received more than five thousand (5000) complaints of minor nature dispute, frictions and anomalies based on incompatible revenue laws.

\section{Corruption}

Absence of clear, designated and transparent revenue laws increases complexities in the system. It enhances probability of using local discretion by respective official of government agencies. Use of discretion induces officials to seek rent in clumsy situation. This rent seeking culture increases in presence of more ambiguous laws. Ultimately, corruption in the society increases.

"One of the biggest curses from which Sub-continent is suffering, I do not say that other countries are free from it, but, I think our condition is much worse, is bribery and corruption. That really is a poison. We must put it down with an iron hand."

(Quaid-i-Azam) 
Corruption is defined as, "the abuse of public offices for private gains" [World Bank (1997)]. Corruption can affect resource allocation in two ways. First, it can change (mostly) private investors' assessments of the relative merits of various investments. This influence follows from corruption-induced changes in the relative prices of goods and services, and of resources and factors of production, including entrepreneurial talent. Second, corruption can result in resource misallocation when the decisions on how public funds will be invested, or which private investments will be permitted, are made by a corrupt government agency. The misallocation follows from the possibility that a corrupt decision-maker will consider potential 'corruption payments' as one of the decision criterion [Aman and Ahmad (2006)].

Corruption has its multiple ramifications. In his supporting argument that Pakistan official system is plagued with corruption, Chaudhry (2006) notes that often it has become our culture and routine, pointing out the moral deterioration of our society (selling, teaching, nepotism etc.) posing a question that 'Is Corruption a moral deterioration, alteration from original, the inability of the system to implement or a culture?'

The expansion of corruption in the decade of transition has coincided with a sharp, initial decline in output and significantly higher levels of poverty and inequality across the region [World Bank (2000)]. Aman and Ahmad (2006) are of the view that there is sufficient documentary evidence of considerable economic and social costs of corruption. Patwari is feeding many of his seniors on different occasions, for example hospitality of any VIP in the district becomes responsibility of Patwari.

Corruption weakens public service delivery, misdirects public resources, and holds back the growth that is necessary to pull people out of poverty because it might be the poorest who is paying for it. As a result, some countries risk becoming trapped in a vicious circle in which pervasive corruption reduces public revenues, undermines public trust, and weakens the credibility of the state, unless decisive leadership can push through the necessary reforms.

State Capture. It refers to the actions of individuals, groups, or firms both in the public and private sectors to influence the formation of laws, regulations, decrees, and other government policies to their own advantage as a result of the illicit and nontransparent provision of private benefits to public officials.

While state capture encodes advantages for particular individuals or groups in the basic legal or regulatory framework, administrative corruption refers to the intentional imposition of distortions in the prescribed implementation of existing laws, rules, and regulations to provide advantages to either state or non-state actors as a result of the illicit and non-transparent provision of private gains to public officials.

Azfar (2006) notes that corruption has been shown to lead to lower investment, slower growth, misallocated resources, poorer health and education outcomes and more restrictions on international trade thereby undermining the economic development.

Several studies have demonstrated a relationship between corruption and income inequality. The theoretical foundations for this relationship are derived from rent theory and draw on the ideas of Susan (1978) and Kruger (1974), among others. Propositions include: (a) Corruption may create permanent distortions from which some groups or individuals can benefit more than others, (b) The distributional consequences of corruption are likely to be more severe when corruption is persistent. 


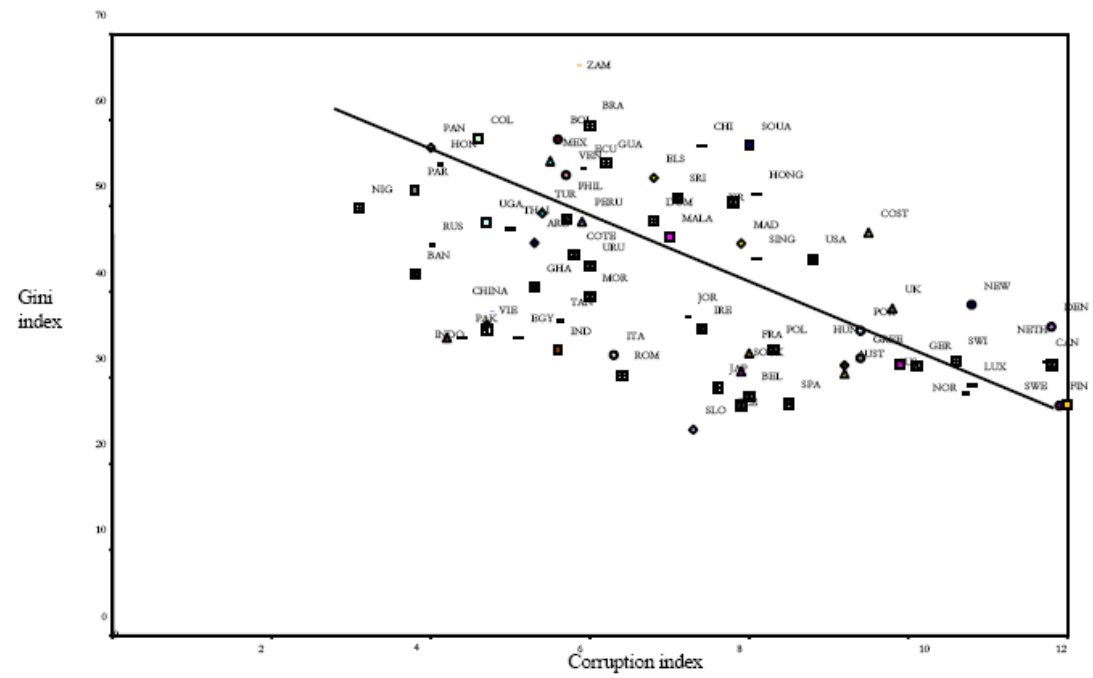

Relationship between Corruption and Income inequality (Source: Aman and Ahmad, 2000)

Using the panel data of 71 developing and developed countries Aman and Ahmad (2006) found that the relationship between corruption and income equality is considerably negative. A central message of corruption and income inequality relationship suggest that corruption has significant distributional implications and, given its negative efficiency implications, should be considered harmful to both growth and equity. Therefore, policies that reduce corruption will also improve income distribution.

\section{EMPIRICAL ANALYSIS}

Implication of incompatible revenue laws are empirically observed and analysed. In this regard primary data is collected from district Islamabad. Data is described in Tables 1 and 2 for instance in Islamabad district only around eleven thousand cases were filed in civil courts during 2006. About 44 percent cases are based on incompatibility of land revenue laws. Ambiguity in laws leads to increase in civil litigation, thereby, cost to society increases.

Table 1

Annual Civil Cases in Islamabad

\begin{tabular}{cccc}
\hline Year & $\begin{array}{c}\text { Total Civil Nature } \\
\text { Cases }\end{array}$ & $\begin{array}{c}\text { Land Dispute Based } \\
\text { Cases }\end{array}$ & $\begin{array}{c}\text { Miscellaneous } \\
\text { Cases }\end{array}$ \\
\hline 2007 & 6,266 & 3726 & Not Available \\
2006 & 10,950 & 4,780 & 5,170 \\
\hline Source: District Courts, Islamabad. & &
\end{tabular}

Source: District Courts, Islamabad. 
Table 2

Annual Criminal Cases in Islamabad District

\begin{tabular}{lccc}
\hline & Total Criminal Cases & Land Dispute & \\
Year & Registered & Based Cases & Miscellaneous Cases \\
\hline 2007 & 4487 & 1086 & 3401 \\
2006 & 4333 & 1065 & 3268 \\
\hline
\end{tabular}

Source: District Courts, Islamabad.

Around 4487 criminal cases were registered during 2007. Share of incompatible land revenue law based cases in total criminal cases is around one fourth. Thus these ambiguous and old laws directly affects crime rate in the district.

In addition to above categories of cases individuals also register their complaints in revenue administration/courts pertaining to land, their property rights and disputes. On average 52,000 per annum petitions/complaints are filed in Islamabad with respect to land related issues.

\section{CONCLUSION AND POLICY RECOMMENDATIONS}

It is observed that incompatible revenue laws directly affect civil litigation, crime rate and transaction cost in the society. Inconsistent laws increase work load on the governance institutions. Work load of civil and criminal courts also increases due to incompatible laws. Quality of service delivery and dispensation of justice is adversely affected by incompatible laws. Risk averse investors normally avoid making investment in such as ambiguous property right regime. Transaction cost to individuals and society increases with ambiguous laws.

Even though the constitution provides the development goals and law plays an important role in the process of development, but a legal vision and strategy compatible with social and economic goals with micro-legal prescription (such as customary laws etc.) under a macro-legal framework is needed. Imposing formal institutional structures on a society with incompatible traditions is unlikely to succeed in bringing about lasting reform. Further the judicial system will lack legitimacy until the other instruments of national sovereignty also win citizen acceptance.

Economic management of today needs to develop an interdisciplinary team, of economists and lawyers.

On the constitutional front the law reform could include:

(1) There needs to be an economic basis of laws relating to economic transactions.

(2) Land revenue system including record keeping to be reformed.

(3) Rationalisation of fee and structure of system.

Owing to significant relationship of corruption to income inequality, policies aiming at reducing it would ultimately have a positive impact on the income inequality. A holistic approach with inclusion of public, private-corporate sector and civil society to address the issues of accountability, transparency, participation, openness and rule of law can help in combating such a situation.

Thus, an effective anti-corruption strategy should: 
(a) encourage the reduction of rents by means of economic liberalisation, deregulation, tax simplification, de-monopolisation and macroeconomic stability; (b) reduce discretion through administrative and civil service reform, including meritocratic recruitment and decentralisation; (c) honest and visible commitment by the leadership to the fight against corruption. The leadership must show zero tolerance for it; and (d) increase accountability - by building up institutions such as auditing and accountancy units, through legal reforms such as judicial strengthening, by encouraging public oversight through Parliament and a more vibrant civil society.

With secured property rights openness to markets and reduced Inequalities in endowments and opportunities can play a large role in growth. There should be transition of land record system, backed by technical support by IFIs, such as the pilot project of digitisation of land use record in Rawalpindi district. Further in this regard all the sale deeds, land transfers and other land title changing should be through a solicitor, which can help in a legal and transparent manner preventing future legal recourses.

\section{ANNEXURE 1}

\section{FORMS OF LEGAL INSTITUTIONS}

If legal institutions are socially taken into account as factual situations, their form must be such that they can actually be conceived of as particular situations. That is to say, as existent. There are three basis forms of particular situations:

(1) The existence of a certain entity.

(2) A certain existing entity having a certain property.

(3) Certain existing entities having a certain connection.

The category of entities can be further divided in two, namely subjects, which can perform acts, and objects, which can be acted upon. With the aid of both distinctions, a classification of particular situations and therefore also of legal institutions can be constructed. The idea is that this classification is exhaustive, because there are subjects and objects, which can only have a limited number of relations [Wessel (2001)].

The different kinds of legal institutions can be characterised as follows [Ruiter (1997, 2001, 2004)]:

Legal Persons: A legal person is a valid legal regime with the form of an entity that can act. Example: the European Community.

Legal Objects: A legal object is a valid legal regime with the form of an entity that can serve as the object of transactions. Example: a conveyable right of ownership.

Legal Qualities: A legal quality is a valid legal regime with the form of a characteristic of a subject. The legal regime regulates the behavioral relation between that particular subject and all other subjects. Example: a person's legal majority.

Legal Status: A legal status is a valid legal regime with the form of a characteristic of an object. The legal regime regulates the behavioral relations between particular subjects responsible for that object and all others subjects. Example: a listed historical monument.

Legal Connections: A personal legal connection is a valid legal regime with the form of a connection between subjects. The legal regime regulates the behavioral relations between those particular subjects. Example: a personal right. 
Legal Configurations: A legal configuration is a valid legal regime with the form of a connection between objects. The legal regime regulates the behavioral relations between particular subjects with certain relations towards each of the objects. Example: an easement, that is, a legal regime with the form of a connection between a servient tenement and a dominant tenement consisting in a burden (e.g. a right of way) laid on the former for the benefit of the latter. All successive owners of the servient tenement are obligated to bear the burden and all successive owners of the dominant tenement are entitled to treat the former as thus obligated.

\section{ANNEXURE 2}

\section{BUNDLE OF RIGHTS}

Schlager and Ostrom (1992) describe five different property rights:

(1) Access, the right to enter a defined physical property.

(2) Withdrawal, the right to obtain the 'products' of a resource (e.g., catch fish, appropriate water, etc.).

(3) Management, the right to regulate internal use patterns and to transform a resource by making improvements.

(4) Exclusion, the right to determine who will have an access right, and how that right may be transferred.

(5) Alienation, the right to sell or lease either or both of the above-mentioned collective-choice rights

\begin{tabular}{lrrrrr}
\hline & \multicolumn{5}{c}{ Bundles of Rights Associated with Types of Owners } \\
\cline { 2 - 6 } & Owner & Proprietor & $\begin{array}{c}\text { Authorised } \\
\text { Claimant }\end{array}$ & $\begin{array}{c}\text { Authorised } \\
\text { User }\end{array}$ & $\begin{array}{c}\text { Authorised } \\
\text { Entrant }\end{array}$ \\
\hline Access & $\mathrm{x}$ & $\mathrm{X}$ & $\mathrm{x}$ & $\mathrm{X}$ & $\mathrm{X}$ \\
Withdrawal & $\mathrm{x}$ & $\mathrm{X}$ & $\mathrm{x}$ & $\mathrm{X}$ & \\
Management & $\mathrm{x}$ & $\mathrm{X}$ & $\mathrm{x}$ & & \\
Exclusion & $\mathrm{x}$ & $\mathrm{X}$ & & & \\
Alienation & $\mathrm{x}$ & & & & \\
\hline
\end{tabular}

\section{REFERENCES}

Alam, Ahmad Rafay (2006) Land Locked: An Examination of Some of the Inefficiencies Affecting Transactions Involving Immovable Property. The Pakistan Development Review 45: 4.

Aman Ullah, M. and Eatzaz Ahmad (2006) Corruption and Income Inequality: A Panel Data Analysis. The Pakistan Development Review 45:4.

Azfar, Omar (2006) The New Institutional Economics Approach to Economic Development: A Discussion of Social, Political, Legal and Economic Institutions. The Pakistan Development Review 45: 4.

Beck, A., et al. (1993) Survey of State Prison Inmates, 1991. Washington, DC: Bureau of Justice Statistics, U.S. Department of Justice. 
Bowers, James W. and John P. Bigelow (1995) The Economics of Relationships and the Limits of the Law. Lsu Law and Economics Working Group Discussion Paper Series, Draft, revised, August 14, 1996.

Chaudhry, M. Azam (2006) Laws as Cultural System: Chaudhry, Mullah and Judge in Pakistan Legal Culture. The Pakistan Development Review 45: 4.

Cole, D. H. (2002) Pollution and Property, Comparing Ownership Institutions for Environmental Protection. Cambridge: Cambridge University Press.

Dietz, T., E. Ostrom, and P. C. Stern (2003) The Struggle to Govern the Commons. Science 302:5652, 1907-1912.

Haq, Muhammad Naeemul (2006) Post-devolution Enforcement of Local and Special Laws. The Pakistan Development Review 45: 4.

Harrison, L. and J. Gfroerer (1992) The Intersection of Drug Use and Criminal Behavior: Results from the National Household Survey on Drug Abuse. Crime and Delinquency 38:4, 422-443.

Hassan, Azhar Nadeem (2006) Law and Order Economic Development and Community based Policing in Context of Pakistan. The Pakistan Development Review 45: 4.

Hassan, Tariq (2006) Governance and Development: The Constitutional Imperative. The Pakistan Development Review 45: 4.

Khan, Foqia Sadiq (2006) Property Rights and Taxonomy of Land Records: A Case Study of Lahore. The Pakistan Development Review 45: 4.

Kruger, Anne O. (1974) The Political Economy of Policy Reform in Society. American Economic Review 64, 291-303.

Ludwig Van den Hauwe (1999) Public Choice, Constitutional Political Economy and Law and Economics. Brussels, Belgium.

Rajan, Raghuram G. (2006) The Persistence of Underdevelopment: Constituencies and Competitive Rent Preservation. The Pakistan Development Review 45: 4.

Root, Hilton L. and Karen May (2006) Judicial Systems and Authoritarian Transitions. The Pakistan Development Review 45: 4.

Ruiter, D. W. (1997) A Basic Classification of Legal Institutions. Ratio Juris 10, 357-371.

Ruiter, D. W. (2001) Legal Institutions. Volume 55 of Law and Philosophy Library. Kluwer Academic Publishers.

Ruiter, D. W. (2004) Types of Institutions as Patterns of Regulated Behaviour. Res Publica.

Schlager, E. and E. Ostrom (1992) Property-rights Regimes and Natural Resources: A Conceptual Analysis. Land Economics 68:3, 249-262.

Siddique, Osama (2006) The Jurisprudence of Dissolutions: Presidential Power to Dissolve Assemblies under the Pakistani Constitution and its Discontents. The Pakistan Development Review 45: 4.

Steins, N. A. (1999) All Hands on Deck, an Interactive Perspective on Complex Common-pool Resources Management based on Case Studies in the Coastal Waters of the Isle of Wight (UK), Connemara (Ireland) and the Dutch Wadden Sea. Ph.D. thesis, Wageningen University.

Susan, Rose-Ackerman (1978) Corruption: A Study in Political Economy. New York: Academic Press. 
Waseem, Mohammad (2006) Constitutionalism in Pakistan: The Lingering Crises of Dyrachy. The Pakistan Development Review 45: 4.

Wessel, R. (2001) De plaats van de Europese Unie in het veranderende bestel van de volkenrechtelijke organisatie. Volume 123. Preadviezen, Mededelingen van de Nederlandse Vereniging voor Internationaal Recht, Chapter De Europese Unie in de internationale rechtsorde, pp.1-78. T.M.C. Asser Press.

Wim van de Griendt_ Institute for Governance Studies University of Twente (2004) A Law and Economics Approach to the Study of Integrated Management of Estuaries. June.

World Bank (1997) The State in a Changing World: World Development Report 1997. Oxford: Oxford University Press.

World Bank (2000) Anticorruption in Transition: A Contribution to the Policy Debate. 